\title{
光反応基ジアジリンを利用した分子生物学的手法の開拓
}

\author{
定金＼cjkstart豊, ${ }^{*, a}$ 畑中保丸 $\star^{b}$
}

\section{Development of New Method for Molecular Biology Using the Photophore, Diazirine}

\author{
Yutaka SADAKANE ${ }^{*, a}$ and Yasumaru HATANAKA ${ }^{b}$ \\ ${ }^{a}$ School of Pharmaceutical Sceinces, Kyushu University of Health and Welfare, 1714-1 Yoshino-cho, \\ Nobeoka City 882-8508, Japan and ${ }^{b}$ Graduate school of Pharmaceutical Sciences, \\ University of Toyama, 2630 Sugitani, Toyama City 930-0194, Japan
}

(Received July 29, 2008)

\begin{abstract}
Formation of a covalent bond using photoreactive groups allows one to maintain the complex between the ligand and its binding protein even under denaturing conditions. Thus, the photoreactive groups functioned as the powerful hook in the fishing of specific binding proteins. This is a very useful feature for developing the efficient and sensitive methods in molecular biology. Among the photoreactive groups, carbene-generating phenyldiazirine is a first choice for the application to the methods because the use of phenyldiazirine seems to be promising for achieving efficient crosslinking. This review describes improvements of phenyldiazirine usability and an application of phenyldiazirine to displayed phage screening. We synthesized the photoreactive diazirine units for a solution to preparing photoreactive ligands. Since the photoreactive units can be easily integrated into physiological ligands such as peptides, proteins, DNAs, and sugars by chemoselective reaction, the biochemists, who are not familiar with organic synthesis, can prepare the photoaffinity ligands using their interested ligands. We applied the phenyldiazirine to screening of displayed phages, and investigated the screening efficiency. The phages displayed specific-binding protein were extremely concentrated by using photoreactive peptide bearing diazirine. High efficiency in the screening is due to carry out intensive washing which removes almost all the unspecific binding phages. Moreover, such application overcomes the unavoidable drawback of photoreactive groups, the low efficiency of crosslinking because the isolated genes can be amplified.
\end{abstract}

Key words _ diazirine; chemical proteomics; chemoselective reaction; Friedel-Crafts reaction; displayed phage

\section{1. 分子生物学的手法へ光反応基を導入する}

分子生物学的手法を用いて研究を始めた頃, 誰も が使えるようなキットとして様々な方法論が提供さ れていることに驚いたことを覚えている，遺伝子の 切り貼り，形質転換，クローニング法など，多種多 様な分子生物学的手法を商業的に手に入れることが できる．例えば，タンパク質同士の相互作用を簡便 に，しかも確実に検出できる酵母 Two-hybrid 法は 1989 年に発表されたが，その数年後には商業的に キットとして販売された. ${ }^{1,2)}$ 酵母 Two-hybrid 法は 技巧のすばらしさのみならず，新規の生物時計遺伝 子を単離するという成功例により本方法論が実用的

a九州保健福祉大学薬学部（干882-8508 宮崎県延岡市 吉野町 1714-1), $b$ 富山大学大学院薬学研究院 (T9300194 富山市杉谷 2630)

*e-mail: sadapon@phoenix.ac.jp

本総説は, 平成 19 年度日本薬学会 128 年会シンポジウ

ムS16 で発表した内容を中心に記述したものである.
であることを証明した. ${ }^{3)}$ さらには，ゲノム解読の 成果を受け，6000 個あまりの酵母のすべてのオー プンリーディングフレームを対象にしたタンパク質 同士の結合について網羅的に調べ，全タンパク質の 相互作用マップを酵母 Two-hybrid 法で作成したこ

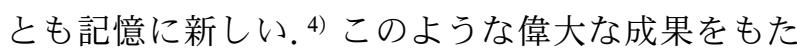
らす方法論までもが，誰もが使える形で提供されて いることが分子生物学の魅力の一つといえよう。分 子生物学的手法の最大の特徵は, 遺伝子を中心に扱 っていることであろう。遺伝子は 1 分子あれば同じ ものを増幅できる．すなわち莫大な分子の中からた つた 1 分子を単離することができればクローニング が成功したことになり，好きなだけ増やして実験に 用いることができる。タンパク質を主体に扱う生化 学的手法ではどれだけの量が回収できたかが重要な 問題であるが，遺伝子を扱う場合には大きな問題に ならない. 
しかしながら，分子生物学研究の世界に身を寄せ てみると, 多くの成果は研究者の努力と執念が実ら せたものであることに気付く，方法論に完璧なもの はない，すべての方法には制限や限界があり，成功 に導くためには命を削って研究を続けるしかない現 状に気付くのである．現場では，さらに高効率で高 感度な分子生物学的手法が求められている。われわ れは，さらに優れた分子生物学的手法の開発を目指 して，その手法に光反応基を導入することを試み た. 光反応基の優れた特徵については後述するが, 光を照射するだけで互いを共有結合で結び付けるこ とができる性質は生体高分子の解析に最適であると 思えたからだ．本総説では，光反応基の優れた特徵 と，光反応基を誰にでも使えるようにした工夫を中 心に紹介する．有機化学と分子生物学というへテロ な分野の融合を円滑に進めるために，この工夫は欠 かせない.

\section{2. 光反応基を導入する利点は何か}

光反応基は, 光エネルギーで容易に分解する化学 官能基である，紫外領域の光を照射すると非常に反 応性の高い中間体を生じる。中間体は最寄りの分子 と電子のやりとりをし，安定な状態に落ち着く，そ の結果，光反応基は最寄りの分子と共有結合をす る。なんらかの分子（例えばリガンド）に，あらか じめ光反応基を仕込んでおけば，その分子が結合す る相手（例えば受容体）と共有結合を形成させるこ とができる．光照射は生体高分子にほとんど影響を 及ぼさないので，生体高分子の活性を保ちながらク ロスリンクを形成することができる．このように光 を照射するだけで互いを共有結合で結び付けられる 性質は，生体高分子の解析に最適であるといえ，光 反応基はリガンドと受容体とのマッチング及び相互 作用機構の解明に有利な化学的性質を有していると いえる. ${ }^{5-7)}$

光反応基の利点は「釣り」に例えて説明すると分 かり易い.リガンドに結合する受容体をクローニン グする実験を，リガンドを餌，受容体を魚として考 えてみる.リガンドと受容体との間には親和性があ り，互いに結合しあう性質がある。ちょうど餌に寄 り付く魚のようなものである. しかしながら，この 釣りには「針」がない。餌を直接，糸に巻き付けて 寄ってくる魚を釣ろうとしているのである [Fig. 1 (a)］。針のない釣りでは釣果は期待できない。光反
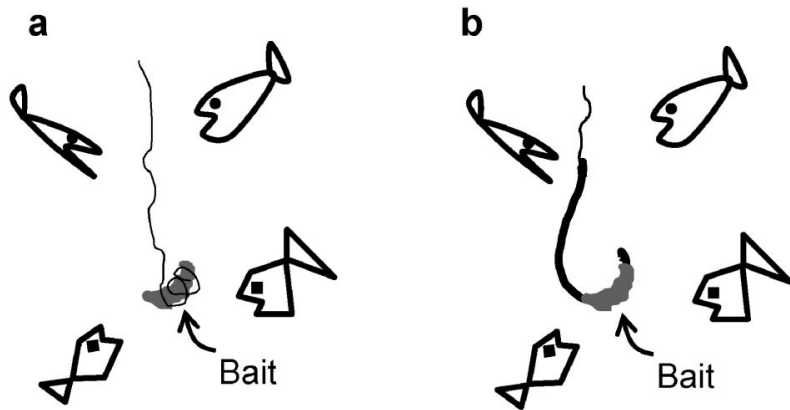

Fig. 1. Fishing the Target Protein with Photoreactive Bait Photoreactive groups function as a fishhook, onto which ligands are placed as fish bait.

応基はこの釣りにおいて「針」の役目をする.リガ ンドに光反応基を装着することは，餌を針につけた ことと同じ意味を持つ [Fig. 1(b)]。餌に呼び寄せ られた魚を針で釣り上げるように，リガンドとの親 和性で近付いた受容体に光を照射すれば，受容体を 確実に釣り上げることができる．光反応基は光を照 射したときにだけ針として働くので，目的の魚が十 分に近付いたときに光照射を行えば目的の獲物だけ を釣り上げることができる.

光反応基という針のおかげで，どのような状態に おかれてもリガンドと受容体の複合体は離れない. 通常，リガンドと受容体との結合は変性状態にする と解離する [Fig. 2(a)]。これはリガンドとの結合 には受容体分子の適切な高次構造が保たれているこ とが必須であるからである．光反応基を装着した光 反応性リガンドを使用すれば，光照射によりリガン ドと受容体とが共有結合で結ばれる。そのため変性 状態でもリガンドと受容体が離れることはない [Fig. 2(b) ]. さらに，光反応基は特異的な結合で あるか非特異的な結合であるかを見分ける力を持つ ている. 光反応基から生じる中間体は非常に高反応 性であるため，その近傍に存在する分子と共有結合 を形成する。リガンドと受容体との結合が特異的で

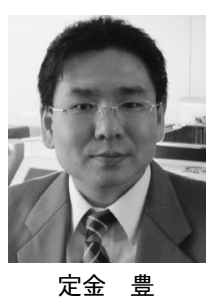

島根県出身, 静岡大学理学部卒業, 山 口大学理学研究科修士課程修了, 岡山 大学自然科学研究科博士課程修了, 産 業総合研究所 NEDO 特別研究員, 富山 大学薬学部助手を経て, 九州保健福祉 大学薬学部講師, 2008 年 4 月より 同 准教授 および京都大学原子炉実験所 客員准教授 博士 (理学), 専門は分析 化学, 分子生物学 


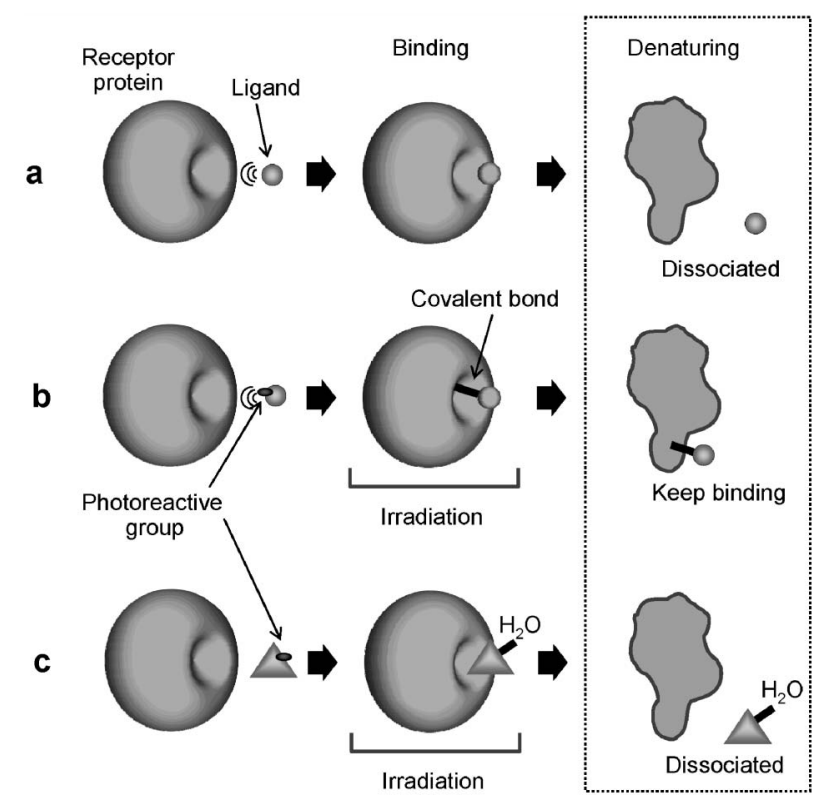

Fig. 2. Ligand-Receptor Complexes in Denaturing Condition (a): The complex easily comes apart in an intact binding because the binding is dependent on the protein's higher ordered structure. (b): Formation of a covalent bond using photoreactive groups allows one to maintain the complex between the ligand and its binding protein even under denaturing conditions. (c): In unspecific binding, the photoreactive groups often form the crosslinking to unrelated compounds such as $\mathrm{H}_{2} \mathrm{O}$.

あれば，リガンドの最寄り分子は受容体であるが [Fig. 2(b) ]，本来結合すべきでない受容体に非特 異的にリガンドが結合すると, 最寄り分子は他の分 子（例えば水分子など）であることが多くなる [Fig. 2(c)]。その結果，リガンドと受容体の間で 共有結合を形成できず，変性状態にすると複合体は 解離してしまう。このように光反応性リガンドを利 用すると特異的な結合だけを選ぶことができる，光 反応基は「離さない」という利点と「選ぶ」という 利点を合わせ持つ分子である。このような分子を分 子生物学的な手法に導入すれば，結合分析の高感度 化，スクリーニングの効率化に役立つであろう。ま た，変性状態でも複合体が保たれているという性質 は，リガンドと受容体のような組み合わせの結合解 析をする手段の幅を大きく広げ，これまで適用でき なかった分析技術を使用することも可能にするだろ う.

\section{3. 光反応基の欠点は分子生物学的手法への導入} で克服できる

分子生物学的手法への光反応基の導入は，分子生 物学的手法を改良するばかりか, 光反応基にとって もその欠点を克服するという相乗効果が期待でき
る. 光反応基の欠点は, 目的タンパク質へのクロス リンク効率が低いことである，これは，光反応基が 生成する中間体の反応性が非常に高いため, 近くに あれば水分子にすらクロスリンクするためであり, 光反応基の化学的性質上，回避できない問題であ る．光反応性 DNA を用いた実験で，20-50\%の高 効率なクロスリンクが報告されていることもある が, 8) 高効率が強調すべき事項であることは，その 他多くの光反応基のクロスリンク効率が低いことを 示している。われわれも光反応性カルモジュリン (CaM) 結合ペプチドと $\mathrm{CaM}$ タンパク質とのクロ スリンク効率を調べてみた（Fig. 3)。光反応性 $\mathrm{CaM}$ 結合ペプチドにビオチンタグを装着し，この タグを頼りにペプチドとタンパク質のクロスリンク 複合体をSDS-PAGE で調べた [Fig. 3(a)]。光照 射時間が長くなるに従い複合体のバンドが濃くな り，おおよそ 60 秒で最大となった。 クロスリンク 効率は, 逆相 HPLC で CaM タンパク質単独とペ プチドータンパク質の複合体とを分離し，それぞれ を定量して決定した [Fig. 3(b)]．クロスリンク効 率は電気泳動で調べた結果と同様に 60 秒で最大に なり，3\%程度と見積もられた。クロリンク効率 が低いという光反応基の欠点は，しばしばクロスリ ンクした標的タンパク質の同定を困難なものにす る。しかし，分子生物学的手法には遺伝子を扱うも のが多く，遺伝子は 1 分子あれば同じものを増幅で きる. 光反応基でクロスリンクする対象が遺伝子, 又はその発現タンパク質であれば，クロスリンクす る効率が低くても問題にならない。遺伝子は単離さ えできれば，いくらでも増やして実験に用いること ができるからだ。このように分子生物学的手法への 光反応基の導入は，両者に利益をもたらす理想的な 組み合わせであるといえる.

\section{4. どの光反応基を使えばよいか}

光反応基にはいくつかの種類があり，それぞれ化 学的に異なつた性質を持つ. どの光反応基を利用す るかは，効率的な分子生物学的手法を作り上げるう えで重要な選択である。現在，生命現象の解明に広 く使われている光反応基は，アジド，ジアジリン， カルボニルの 3 種類である (Fig. 4)。アジドは 300 $\mathrm{nm}$ 付近の光を吸収し, 反応性の高い中間体ニトレ ンを生じる.アジドの利点は合成が容易なことと, 他の光反応基に比べて小さな構造のために修飾によ 
a

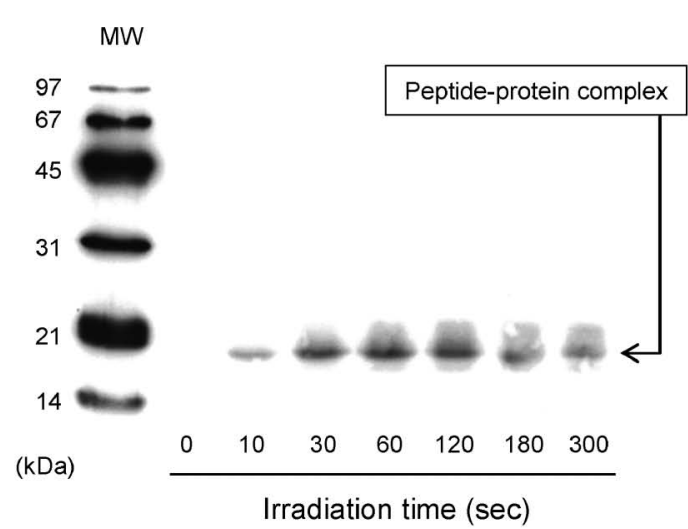

b

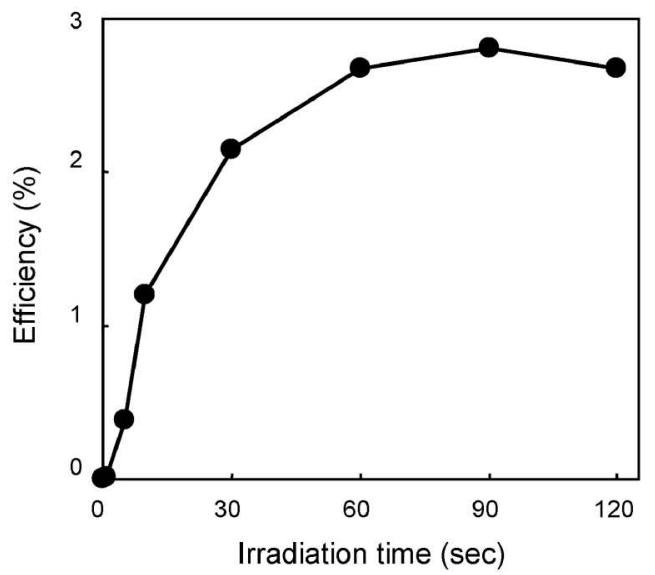

Fig. 3. Crosslinking Efficiency of Photoreactive Group

(a) : Effect of irradiation time for the photoaffinity labeling of calmodulin protein with the photoreactive calmodulin-binding peptide. The mixtures of calmodulin and the peptide were separated by SDS-PAGE and visualized by chemiluminescence of biotin-avidin system. (b): Time course of photoaffinity labeling of calmodulin protein by photoreactive peptide. Photolysis of the complex performed by UV-A irradiation with $30 \mathrm{~W} / \mathrm{m}^{2}$ of $360 \mathrm{~nm}$ light at $0^{\circ} \mathrm{C}$ after incubation at $37^{\circ} \mathrm{C}$ for $10 \mathrm{~min}$ in $50 \mathrm{~mm}$ Tris buffer $(\mathrm{pH} 7.4)$ containing $\mathrm{CaCl}_{2}(5 \mathrm{mM})$, and $\mathrm{NaCl}(0.15 \mathrm{~m})$. After irradiation, photoproducts were chromatographed on reverse-phase HPLC (ODS) with 0.1 \% aqueous trifluoroacetic acid using a gradient of $\mathrm{CH}_{3} \mathrm{CN}$ from 40 to $60 \%$.<smiles>N#[N+]c1ccccc1</smiles>

Azide<smiles>CC1(c2ccccc2)N=NC1(C)C(F)(F)F</smiles>

Diazirine

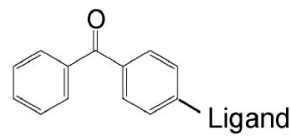

Carbonyl
Fig. 4. Three Major Photoreactive Groups

るリガンドの構造変化を小さくできる点である，商 業的に利用できる誘導体の数も群を抜いており，光 反応基としての使用例も数多い. ジアジリンは 360 $\mathrm{nm}$ 付近の光を吸収し反応性の高い中間体カルベン
を生じる，様々な有機合成条件下でも安定であり， 例えば，二トロ化や Friedel-Crafts 反応の条件に耐 えることができ，固相ぺプチド合成反応においても 無保護で取り扱うことが可能である. ${ }^{9)}$ 反応中間体 カルベンはニトレンよりも高い反応性を示し, 炭素 原子上に共有結合を形成するのでクロスリンクの安 定性においても優れている.10) ニトレンでのクロス リンクはアミノ酸配列を決めるための分解反応によ り切断されてしまうことが報告されており，機能部 位解析に重要なクロスリンク部位の決定が困難であ ると指摘されている. ${ }^{11 ）}$ 光反応基ベンゾフェノンに 代表されるカルボニル基 $(\mathrm{C}=\mathrm{O})$ は， $360 \mathrm{~nm}$ 付近 の光でラジカル性の強い励起三重項状態になり, 主 に相手分子の炭素上の水素原子を引き抜いた結果, 生じた炭素ラジカル対と共有結合を形成する。水分 子とは反応せず，反応する相手がいないときには光 分解せずに繰り返し光反応できる性質を持つため, 一般的に高いクロスリンク効率が期待できる。その 反面, 反応する相手をえり好みすることが指摘され ており,12）光反応基の特色の一つである「獲物を選 ぶ」という利点が発揮できない.

どの光反応基にも利点と欠点があり，どれを利用 すればよいかはそれらの化学的性質からは判断でき ない，実際にクロスリンク実験を行った結果に答え を求めることにする. 光反応基を DNA に導入し, その DNA に結合するタンパク質を調べる実験を行 つた（Fig. 5). 図中の矢印で示したバンドをみる と, ジアジリンは 5 分間の光照射で十分なクロスリ ンク効率が得られたが，ベンゾフェノンでは 20 分 間の光照射でもクロスリンクの効率は低い。光分解 しないためにクロスリンク効率が高いと言われてい るベンゾフェノンであるが，ジアジリンの方が短時 間でクロスリンクを形成した。短時間でクロスリン クを形成する能力は生体高分子を扱う上で都合がよ い. そのほかにも，グルコーストランスポーターを 標的タンパク質として，アジド，ジアジリン，ベン ゾフェノンの光反応性糖鎖で解析した実験, 標的分 子に様々な光反応基を装着した光反応性ペプチドを 用いた実験などから，光反応基ジアジリンが好成績

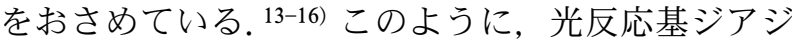
リンは生命現象の解明に優れた特性を持っていると 言える. 効率的な分子生物学的手法を作り上げるた めには，光反応基としてジアジリンを利用するのが 
最善であると結論した.

\section{5. 光反応基を利用するための準備}

光反応基を導入して効率のよい分子生物学的手法 を開発するためには，まず，光反応基を装着した光 反応性リガンドを簡便に作る方法論が必要である. 分子生物学的手法を開発したとしても，光反応性リ ガンドを簡便に作れる技術が伴っていなければ絵に 描いた餅になってしまう。われわれは生体内で重要 なリガンドとして働いているペプチド，タンパク質，

DNA，糖鎖などを簡便に光反応性リガンドにでき る技術を開発した（Fig. 6)。生体高分子の多くは

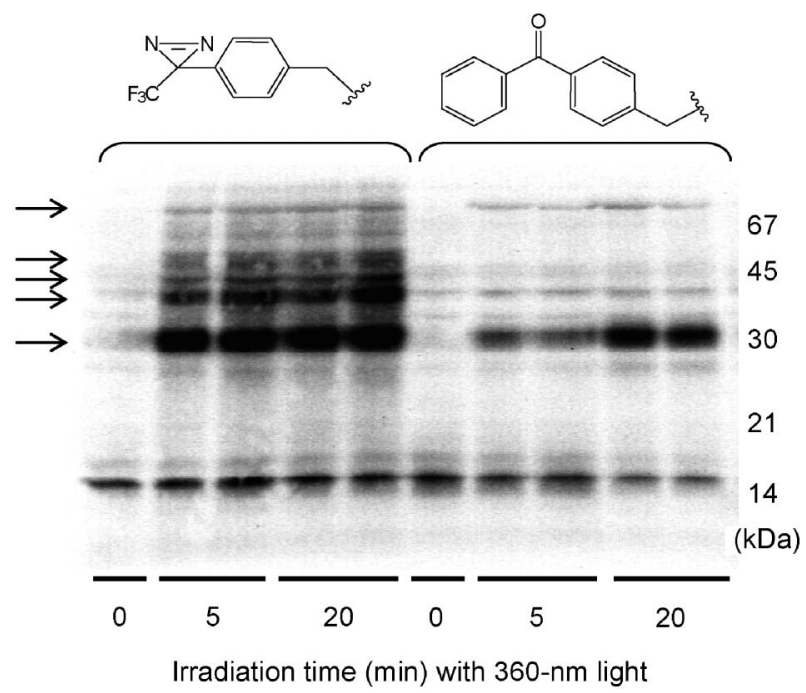

Fig. 5. Comparison of Crosslinking Efficiencies

Photoaffinity labeling to HeLa cell nuclear extract using the photoreactive DNA bearing diazirine or benzophenone is shown. Arrows on left side of the gel indicate the crosslinked complexes.
特異的に反応する官能基を持つている，その官能基 を狙って光反応基を装着できれば，生体高分子の特 異的な部位に光反応基を導入することが可能であ る。例えば，ペプチドやタンパク質中のある部位に システイン残基を導入すれば，そのチオール基に特 異的に光反応基が導入できる．また，糖鎖の還元末 端のアルデヒド基も光反応基を導入するのに便利な 官能基である。DNA のような単位構造物が多数結 合した構造分子でも，合成時にリン酸基の 1 つをチ オリン酸基に置き換えれば，部位特異的に光反応基 を導入することができる，生体高分子の特異的な官 能基に導入可能な光反応基ジアジリン化合物を作製 し，光反応ユニットと名付けた. チオール基と特異 的に反応するユニット [Fig. 6（化合物 6) ] は，中 性付近でシステイン残基を持ったペプチドやタンパ ク質に混ぜるだけで，チオール基特異的に導入する ことができ，反応の特異性，収率ともに非常に高 く，簡単に光反応性ペプチドやタンパク質を作製す ることができる. ${ }^{17)}$ 臭化物であるユニット（化合物 4）は，DNAのリン酸基の一部をチオリン酸基で 置き換えて合成した $\mathrm{S}$ 化 DNA と混合するだけで簡 単に光反応性 DNA を作製することができる. ${ }^{16)} ア$ ミノオキシ基を持つユニット（化合物 7）はアルデ ヒド基と特異的に反応し，糖鎖の還元末端に特異的 に導入できる. ${ }^{18)}$ 官能基特異的な導入方法とは異な るが，ペプチド固相自動合成機を使用して光反応性 ペプチドを作製することを考え，ジアジリンを持つ た光反応性アミノ酸ユニット（化合物 5）を作製し

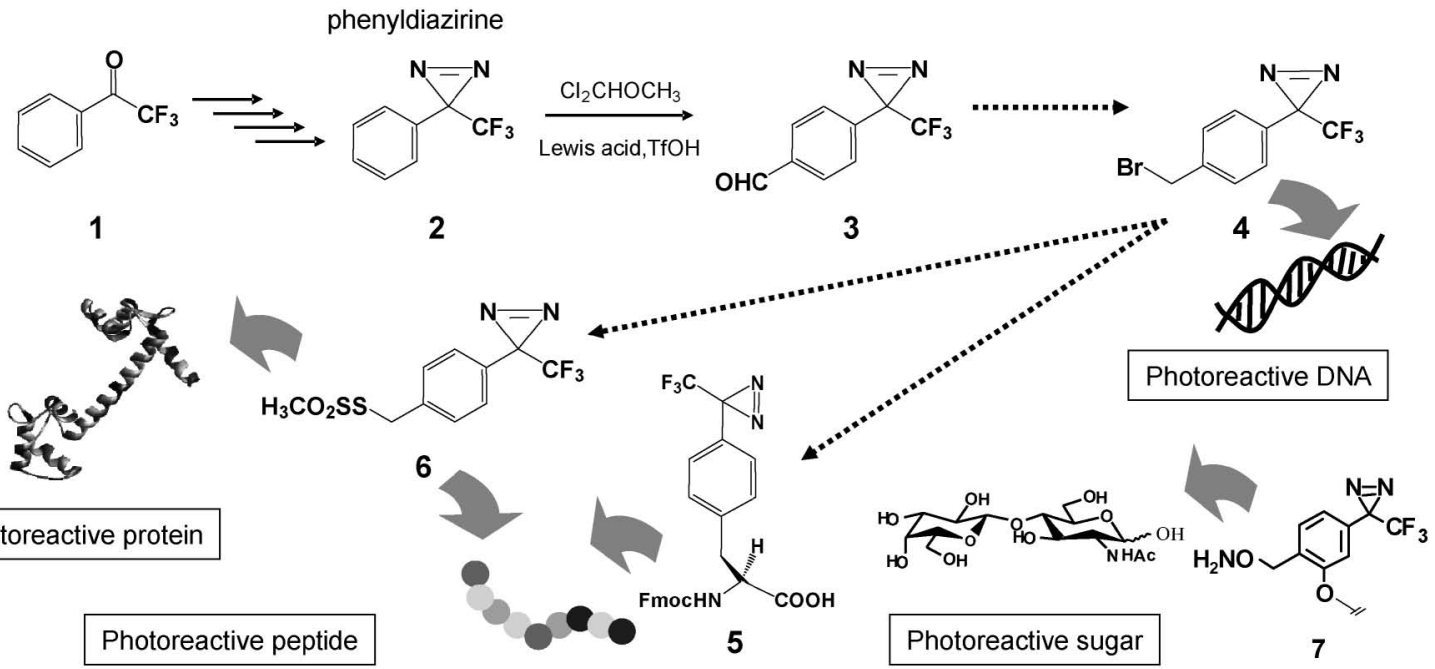

Fig. 6. Photoreactive Units and Their Syntheses 
た．側鎖であるジアジリンを保護することなく合成 が可能で通常の Fmoc アミノ酸と同様に使用するこ とができる. ${ }^{19)}$ このような光反応ユニットが開発さ れたことにより，単に混ぜるだけでタンパク質，ぺ プチド，DNA，糖鎖を光反応性リガンドにするこ とができるようになった，混ぜるだけであるので, 実験を始めたばかりの研究者でも簡単に光反応性リ ガンドを作製することができる，混ぜたあとにカラ ムで精製するステップを考慮しても，数日で光反応 性リガンドを得ることができ，誰もが簡単・迅速に 作製できる環境が整つた.

われわれはさらに，光反応ユニットの合成方法に ついても改良を加えた（Fig. 6). 2,2,2-trifluoro-1phenyl-ethanone（化合物 1) から phenyldiazirine （化合物 2）を数百グラム単位で容易に大量合成する 方法は確立されている. ${ }^{20)} こ の$ phenyldiazirine のべ ンゼン環上に足掛かりとなる置換基を選択的に導入 することができれば，光反応ユニットを大量に作製 することができる。ベンゼン環への置換基導入の手 掛かりとしてホルミル基を選び，ルイス酸として五 フッ化アンチモン $\left(\mathrm{SbF}_{5}\right)$ 又は四塩化チタン $\left(\mathrm{TiCl}_{4}\right)$ を使用し，トリフルオロメタンスルフォン酸 $(\mathrm{TfOH})$ の存在下, phenyldiazirine の $\mathrm{Cl}_{2} \mathrm{CHOCH}_{3}$ による Friedel-Crafts 反応により，パラ位がアルデヒド置 換されたフェニルジアジリンアルデヒド（化合物 3)

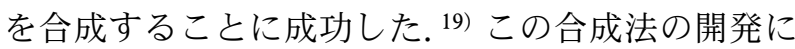
より, 数百グラム単位のフェニルジアジリンアルデ ヒドを手に入れることが可能となり，アルデヒドか ら容易にかつ高収率でエステル $\left(-\mathrm{CO}_{2} \mathrm{CH}_{3}\right)$ ，アル コール $\left(-\mathrm{CH}_{2} \mathrm{OH}\right)$, 臭化物 $\left(-\mathrm{CH}_{2} \mathrm{Br}\right.$, (化合物 4)), メタンチ才硫酸化合物 $\left[-\mathrm{CH}_{2} \mathrm{SSO}_{3} \mathrm{CH}_{3}\right.$, (化合物 5) $]$ に変換できる，さらに，ジアジリン型の光反応性ア ミノ酸の合成法についても検討した。これまで光反 応性アミノ酸の光学活性体は，ラセミ体の酵素によ る限定分解で得る方法と，キラルなニッケル複合体 存在下で不斉合成する方法で行われていた。 ${ }^{21,22)}$ 前 者の方法では酵素処理が制限となり, 後者の方法で は高価なキラルな複合体を等量用いる必要があるこ とから大量合成はできない。われわれはシンコニジ ン誘導体を用いた触媒的不斉アルキル化により，光 反応性アミノ酸の光学活性体を高収率で大量合成で きる方法を確立した. ${ }^{19)}$ このようにジアジリンの光 反応ユニットを大量に合成する方法を確立した。試
薬メーカーから光反応ユニットを入手できるように なれば，本当の意味で誰もが使える光反応ユニット 化技術を確立できたことになる．商業化の難関の 1 つが突破できた意味で，上記の光反応ユニットの大 量合成法の開発は重要な成果であるといえる.

\section{6. 分子生物学的手法への光反応基の導入例}

ジアジリン型光反応性アミノ酸 [Fig. 6（化合物 5) ] を利用して，光反応性 $\mathrm{CaM}$ 結合ペプチドを作 製し，分子生物学的手法の 1 つである提示ファージ のスクリーニング法に導入した例を紹介する（Fig. 7)。CaM 結合ペプチドとして 17 残基のアミノ酸か ら構成される人工配列を使用し，タンパク質との結 合に重要であることが報告されている $N$ 末端から 3 残基目のトリプトファン残基 ${ }^{23)}$ を光反応性アミノ 酸に置き換えて合成した [Fig. 7(a) ].Fmocアミ ノ酸を用いる通常の方法でペプチド固相自動合成機 を使って合成し， $N$ 末端にビオチンを導入した。

$\mathrm{CaM}$ タンパク質を提示したファージに対して 100000 倍量の野生株ファージを含む混合溶液を調 製し，1 回のスクリーニングで $\mathrm{CaM}$ 提示ファージ が何倍に濃縮されるかを調べた［Fig. 7(b)]。フ

a

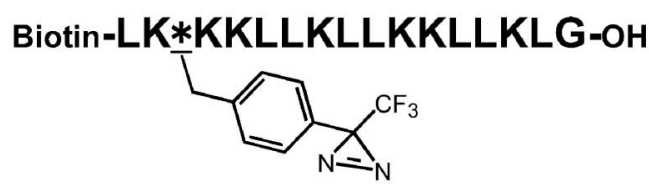

* :Photoreactive amino acid

b

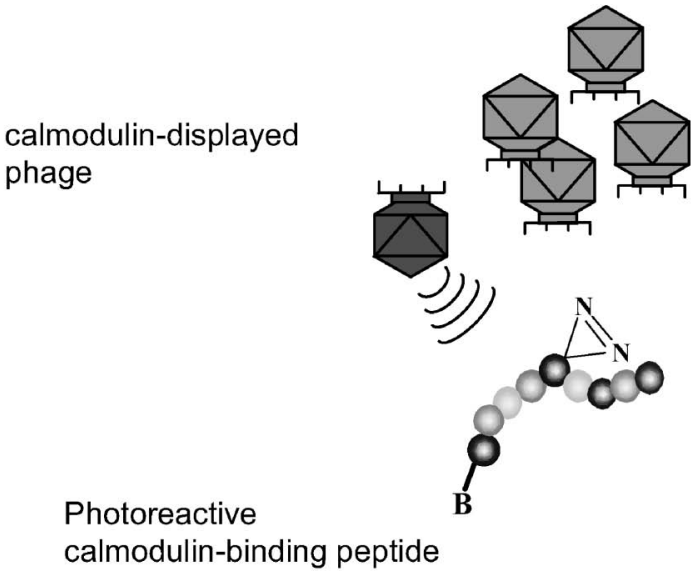

Fig. 7. Photochemical Screening of Displayed Phage

(a): Photoreactive calmodulin-binding peptide prepared with Fmocphotoreactive amino acid. (b): Scheme of photochemical screening of displayed phage with the photoreactive peptide. 
アージの混合液中に光反応性 $\mathrm{CaM}$ 結合ペプチドを 加え，しばらく静置したのち，光照射を行った．徹 底的に洗浄したのちに残つたファージをプレートに 撒き，プラークハイブリダイゼーションによって $\mathrm{CaM}$ 提示ファージの数を計測した。 その結果，従 来のスクリーニング法の濃縮率が 100 倍以下であっ たのに対し，1 回の光化学的スクリーニングでは約 13000 倍に CaM 提示ファージが濃縮できることが 明らかになつた．分子生物学的手法の 1 つである提 示ファージのスクリーニング法に光反応性リガンド を導入することで，非常に効率の高いスクリーニン グを実施することができた。

\section{7. まとめ}

生体内の結合は可逆的なものであり，それらは水 素結合や疎水結合などの弱い結合の総和としてなり 立っている。そのために結合力（親和性）の強さは 様々であり，スクリーニングとは様々な親和性のも のの中から親和性の高いクローンを選択することで ある [Fig. 8 (a) 左図]．親和性の低いクローンは洗 浄で取り除かなければならないが，親和性が幅広く 分布しているためにどれ位の強度で洗浄してよいか 定まらず，非特異的な結合のクローンが残り易い [Fig. 8 (b) 左図]。さらに, 親和性の高いクローン の数は低いクローン数に比べて極めて少ないので, 目的のクローンを取り出すことは難しい。このスク

a

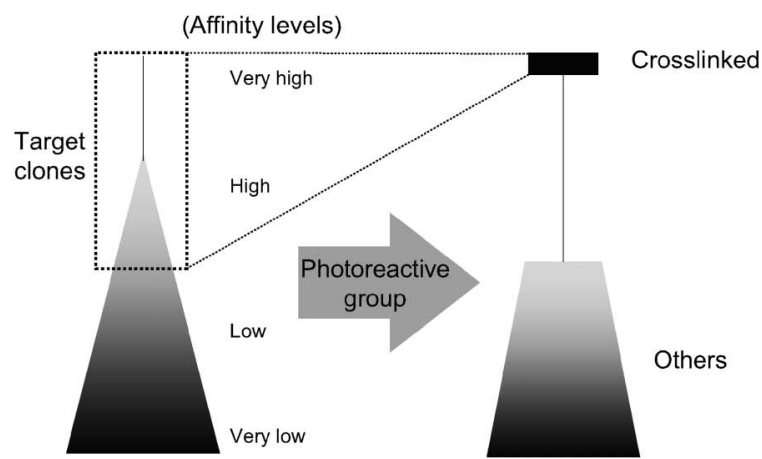

No. of clones No. of clones

b

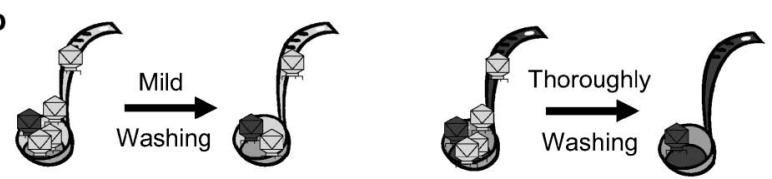

Fig. 8. Roles of Photoreactive Group in Screening Experiments
リーニングに光反応基を導入すると，光反応基が持 つ利点である「離さない」と「選ぶ」という性質に より，特異的に結合している親和性の高いクローン に共有結合を形成できる。 その結果，（クロスリン クされた）高い親和性を持つクローンとそれ以外の 二つの状態に分けることができ [Fig. 8 (a) 右図], 界面活性剂を含むような強力な洗浄液で徹底的に洗 浄することが可能になる [Fig. 8 (b) 右図]。このよ うな理由でフォトパニング法は非常に効率的なもの になったと考えている.

光反応基ジアジリンは生命現象の解明に優れた性 質を持つ. 生体高分子と混ぜるだけで光反応性リガ ンドに変換できるような光反応ユニットを開発し, 簡便にタンパク質，ペプチド，DNA，糖鎖を光反 応性リガンドにできるようになった．分子生物学的 手法に光反応基ジアジリンを導入する試みは始まっ たばかりであるが，提示ファージのスクリーニング において効率が上昇することを確認できた。今後も 様々な分子生物学的手法に光反応基ジアジリンを導 入し，新しい方法論の開発を進めていきたい.

謝辞 本論文の作成に当たりご協力頂いた木葉 敬子助手に感謝します。研究の一部は, 科学研究費 補助金（奨励研究，萌芽研究，基盤研究 $\mathrm{B}$ 及び C), 文部科学省特定研究及び武田科学振興財団の 助成の下に行われました.

\section{REFERENCES}

1) Fields S., Song O.-K., Nature, 340, 245-246 (1989).

2) Chien C.-T., Bartel P. L., Sternglanz R., Fields S., Proc. Natl. Acad. Sci. U.S.A., 88, 9578-9582 (1991).

3) Gekakis N., Saez L., Delahaye-Brown A.-M. Myers M. P., Sehgal A., Young M. W., Weitz C. J., Science, 270, 811-815 (1995).

4) Uetz P., Glot L., Cagney G., Mansfield T. A., Judson R. S., Knight J. R., Lockshon D., Narayan V., Srinivasan M., Pochart P., Qureshi-Emlli A., Li Y., Godwin B., Conover D., Kalbfleisch T., Vijayadamodar G., Yang M., Johnston M., Fields S., Rothberg J. M., Nature, 403, 623-627 (2000).

5) Dormán G., Prestwich G. D., Trends Biotech., 18, 64-77 (2000). 
6) Dormán G., Top. Curr. Chem., 211, 169-225 (2000).

7) Hatanaka Y., Sadakane Y., Curr. Top. Med. Chem., 2, 271-288 (2002).

8) Shigdel U. K., Zhang J., He C., Angew. Chem., Int. Ed., 47, 90-93 (2008).

9) Hatanaka Y., Nakayama H., Kanaoka Y., Rev. Heteroatom Chem., 14, 213-243 (1996).

10) Hatanaka Y., Yakugaku Zasshi, 114, 619-636 (1994) .

11) Maliarik M. J., Goldstein I. J., J. Biol. Chem., 263, 11274-11279 (1988).

12) Wittelsberger A., Thomas B. E., Mierke D. F., Rosenblatt M., FEBS Lett., 580, 18721876 (2006).

13) Yang J., Clark A. E., Kozka I. J., Cushman S. W., Holman G. D., J. Biol. Chem., 267, 10393-10399 (1992)

14) Weber P. J. A., J. Pept. Res., 49, 375-383 (1997).

15) Tate J. J., Persinger J., Bartholomew B., Nucleic Acids Res., 26, 1421-1426 (1998).
16) Sadakane Y., Takagi T., Tomohiro T., Tsurusawa K., Konoha K., Kawahara M., Hatanaka Y., Photomed. Photobiol., 26, 3540 (2004).

17) Kaneda M., Sadakane Y., Hatanaka Y., Bioconjug. Chem., 14, 849-852 (2003).

18) Hatanaka Y., Kempin U., Park J.-J., J. Org. Chem., 65, 5639-5643 (2000).

19) Nakashima H., Hashimoto M., Sadakane Y., Tomohiro T., Hatanaka Y., J. Am. Chem. Soc., 128, 15092-15093 (2006).

20) Brunner J., Senn H., Richards F. M., J. Biol. Chem., 255, 3313-3318 (1980).

21) Nassal M., J. Am. Chem. Soc., 106, 75407545 (1984).

22) Fishwick C. W. G., Sanderson J. M., Findlay J. B. C., Tetrahedron Lett., 35, 4611-4614 (1994).

23) O’Neil K. T., Wolfe Jr. H. R., Erickson-Viitanen S., DeGrado W. F., Science, 236, 14541456 (1987). 